\title{
MANAGEMENT OF THE COLLECTION OF SOCIAL INSURANCE CONTRIBUTIONS
}

Agnė Andrulienė, Master of Public Administration, Vilnius University Šiauliai Academy, Lithuania;

Teodoras Tamošiūnas, Prof., Vilnius University Šiauliai Academy, Lithuania teodoras.tamosiunas@gmail.com

\begin{abstract}
The article analyses the social security system and the social insurance situation in Lithuania. The focus is on the collection of social insurance contributions and coercive measures to recover unpaid contributions. It has been established that a general policy of improving the conditions of the state economy, promoting the development of the country's economy and reducing the possibilities to avoid taxes, is very important for increasing the efficiency of the collection of state social insurance contributions. It is necessary to move to a universal electronic exchange of information in the social security system and closer cooperation with business and public sector institutions.
\end{abstract}

Key words: social insurance, taxes, collection and recovery of contributions

\section{INTRODUCTION}

The most important source of public funds is taxes. The Law on Tax Administration of the Republic of Lithuania defines a tax as a pecuniary obligation imposed on the payer by the state [1]. This tax liability is understood as a lever for state economic and market regulation. The concept of tax administration is defined in this Law as the implementation of the functions of a tax administrator, the performance of the duties and the exercise of rights of a tax administrator and a taxpayer. Tax administration is a very topical problem for both Lithuania and the European Union, as VAT fraud alone costs the budgets of EU member states about 170 billion per year [2]. Tax administrators typically experience taxpayer disobedience to the law (including fraud) or taxpayer insolvency [2].

The financial activity of the state, in obtaining taxes and improving the investment, is effective only if an optimal tax administration mechanism is created, which harmonizes the possibilities of budget supplementation and eliminates the preconditions for tax evasion. There are closely related economic and legal instruments in the tax administration that regulate the monetary relations between the state and taxpayers due to the mobilization of tax revenues to the state budget, following the principles of mutual responsibility. The main 
methods of tax administration are tax planning, tax management and tax control. Tax administration is part of the management of the tax system. It is improved on the basis of historical experience, modern achievements of economic science and practice, creating conditions for the operation of planning, regulation, control as well as setting rules of accounting and analytics. Low quality of inspections, lack of evidence of revealed tax violations, sanctions, increase in the number of one-day firms, etc., all indicate a poor tax administration mechanism [3].

The article aims to examine the situation of the management of the collection of state social insurance contributions in Lithuania and to provide directions for the improvement of the management of this collection.

\section{TAXATION AND SOCIAL SECURITY IN LITHUANIA}

Social security in Lithuania is defined as a system of socio-economic maintenance measures established by the state, which provides the funds and services necessary for subsistence to citizens who, due to the reasons provided by law, are unable to make a living from work or receive other income [4]. In Lithuania, social security covers three components: 1) social insurance, which is financed by special contributions and is intended to provide for persons who have lost income due to a specific event (e.g. unemployment, illness, old age); 2) social support - benefits in cash or benefits in kind, including social services; 3) special social benefits, pensions (e.g. victims, soldiers, scientists) [5]. The most important part of social security is social insurance, as it covers almost the entire population of the country: pensions, sickness and maternity (paternity), health, unemployment insurance and insurance against accidents at work and occupational diseases. Social assistance includes cash social assistance (social pensions, family allowances, compensation for funeral, heating and other expenses) and social services (social care institutions, care for the elderly, the disabled, orphans, hostels for homeless, day centres, help and nursing at home).

The countries of the European Union, faced with the phenomena of economic development and globalization, are looking for new ways to ensure the adequacy and sustainability of the social security system. One of the tasks is to increase the number of social security contributors not only by attracting new contributors but also by collecting income from the unaccounted (shadow) economy. The fight against the unaccounted economy and the related state social insurance reforms must be aimed at improving the efficiency of system management and the use of social insurance principles. 
Lithuania's progress strategy "Lithuania 2030" envisages a business-friendly environment, as it is one of the key factors determining the development of a smart, knowledge and entrepreneurship-based economy [6].

\section{ENFORCEMENT MEASURES IN THE ADMINISTRATION OF CONTRIBUTIONS}

The Rules for the Application of Coercive Measures [7] determine the actions of territorial divisions of the Board of the State Social Insurance Fund when persons fail to pay accrued state social insurance contributions, compulsory health insurance contributions, or other contributions on time. These rules confer the right to recover accrued contributions or benefits to the budget of the Fund in the non-dispute procedure. The use of coercive measures is strictly regulated by the order and deadlines of decision-making, sending and service of enforcement documents.

Combating taxpayers' disobedience to the law, in 2015, the money restriction information system PLAIS was implemented in Lithuania. This system manages the data on the restriction of funds centrally: it transmits the restriction and write-off instructions to the banks and distributes the debtor's funds to the creditors proportionally. The implementation of PLAIS brought together the information resources of 19 different institutions related to the accounting of personal funds and debt collection.

Taxpayer insolvency is another reason for the use of coercive measures. The Law on Bankruptcy of Enterprises of the Republic of Lithuania defines the insolvency of a company as the state of the company when the company defaults and the company's overdue liabilities (debts, work in progress, etc.) exceed half of the value of its assets. The insolvency of natural persons is regulated by the Law on Bankruptcy of Natural Persons of the Republic of Lithuania [8]. Insolvency is associated with financial difficulties, loss of solvency, and the delay in using appropriate measures to eliminate the causes of insolvency becomes the cause of bankruptcy [9]. Table 1 shows the internal and external factors that determine insolvency.

Table 1. Internal and external factors determining insolvency

\begin{tabular}{|l|l|}
\hline \multicolumn{1}{|c|}{ Group } & \multicolumn{1}{c|}{ Factors (reasons) } \\
\hline \multicolumn{2}{|l|}{ Internal factors determining insolvency } \\
\hline $\begin{array}{l}\text { Managers' competence } \\
\text { and general } \\
\text { organizational } \\
\text { characteristics }\end{array}$ & $\begin{array}{l}\text { Improper management, lack of managerial experience, } \\
\text { unprofessionalism of managers, lack of competence }\end{array}$ \\
\hline
\end{tabular}




\begin{tabular}{|l|l|}
\hline $\begin{array}{l}\text { Financial and } \\
\text { operational analysis, } \\
\text { management of the } \\
\text { effectiveness of } \\
\text { prevention measures } \\
\text { based on them }\end{array}$ & $\begin{array}{l}\text { Inadequate information collection and planning, lack of } \\
\text { financial and economic analysis, ignoring negative changes in } \\
\text { operations, inadequate or delayed insolvency prevention } \\
\text { measures }\end{array}$ \\
\hline Other reasons & $\begin{array}{l}\text { Deferral of payment, age of the company, insolvency of } \\
\text { customers, occurrence of crises, high current expenses compared } \\
\text { to income }\end{array}$ \\
\hline External factors determining insolvency \\
\hline Economic factors & $\begin{array}{l}\text { GDP decline, inflation growth, tax system instability, } \\
\text { unemployment growth, informal economy development, } \\
\text { economic growth slowdown }\end{array}$ \\
\hline Market factors & $\begin{array}{l}\text { Decline in the domestic market, increasing domestic and } \\
\text { international competition, loss or bankruptcy of major customers } \\
\text { or suppliers, significant decline in demand, foreign exchange } \\
\text { market instability, interest rate growth, restricted competition }\end{array}$ \\
\hline Other factors & $\begin{array}{l}\text { Political instability, corruption in the public sector, instability of } \\
\text { the legal system and legal framework, strengthened system of } \\
\text { regulatory and legal normative acts, natural disasters, } \\
\text { deterioration of the criminal situation }\end{array}$ \\
\hline
\end{tabular}

Source: Compiled by the authors according to [9]

Bankruptcy reflects the last state of a crisis situation in a company when it is unable to meet its obligations to creditors. Bankruptcy is recognized as an integral element of market relations, performing significant functions in the country's economic life: it forces companies in difficulty to seek new ways to improve and restructure their operations and naturally removes inefficient participants from the market [10]. Not only companies but also individuals go bankrupt or become insolvent. Membership of the European Union has opened up opportunities for citizens of the Member States to change their place of residence and place of business throughout the EU. This has led to an increasing number of situations in which natural persons facing difficulties in meeting their financial obligations and wishing to get rid of their debts are exercising their right to free movement in search of a more favourable legal climate in other European Union countries [11].

\section{MANAGEMENT OF THE STATE SOCIAL INSURANCE SITUATION IN} LITHUANIA

Gross domestic product (GDP) per capita is one of the main indicators of the country's economic development, showing the nature and speed of economic development, 
opportunities for the growth of public welfare and trends. GDP per capita in Lithuania has been growing rapidly over the last two decades: from $€ 3.8$ thousand in 2000 up to $€ 9.1$ thousand in 2010 and up to $€ 17.5$ thousand in 2019 [12]. Rising GDP per capita reflects economic growth; at the same time, rising revenues ensure a steady increase in contributions to the state budget.

Another economic factor that has a significant impact on contributions to the state budget is the average monthly wage. As Figure 1 shows, this indicator in Lithuania has also been growing rapidly in the last decade and in 2018 it already exceeded $€ 700$ (Net), and in the third quarter of 2020, it reached $€ 927$ (Net) [12].

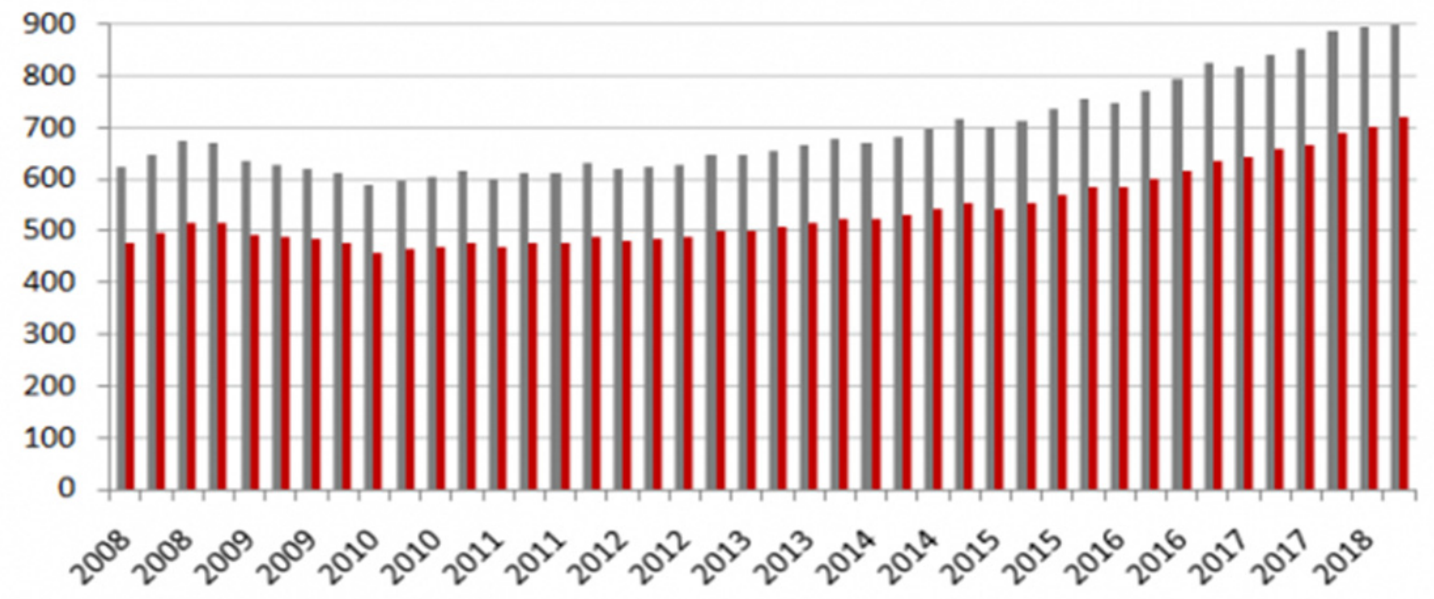

Fig. 1. Average monthly salary in Lithuania, Eur (Gross and Net), Source: [12]

The financial basis of state social insurance consists of an independent budget of the State Social Insurance Fund of the Republic of Lithuania, which is not included in the state or municipal budgets. On December 23, 2020, the Seimas of the Republic of Lithuania approved the draft law on the approval of indicators for the year 2021 of the budget of the State Social Insurance Fund for 2021 [13]. About $€ 5.13$ billion revenue of the State Social Insurance Fund for 2021 has been approved and $€ 4.99$ billion costs. Revenue of the Fund's budget in 2021 has been calculated, using the rates of social security contributions of 1.47 percent of policyholders and 12.52 percent of the insured.

For the year 2021, €2,558 million is planned for insured state social insurance contributions, $€ 344$ million for state social insurance contributions of policyholders, and $€ 2,119$ million of appropriations from the state budget. The largest part of the Fund's expenditures will be spent on social insurance pensions - about $€ 3.8$ billion. More than a billion euros are spent on 
sickness, maternity and unemployment social insurance.

In 2021, the total number of insured persons will be about 1 million, 502 thousand, the number of old-age pensioners - about 611.5 thousand, and the number of all paid state social insurance pensions in 2021 is forecasted to be about 1 million, 268 thousand. The average old-age pension in 2021 will increase by almost 10 percent and will amount to about $€ 440$ [13].

The Ministry of Social Security and Labour of the Republic of Lithuania is responsible for the legislation in the field of social security and labour, and the State Social Insurance Fund Board under the Ministry of Social Security and Labour ensures the implementation of the Law on State Social Insurance and other legal acts regulating the implementation of legislation at the state level. Ten territorial divisions are subordinated to the Board, which collect and recover the state social insurance contributions in the territories assigned to them, process the data of insured persons, control the legality and validity of temporary incapacity for work and ensure the correct and timely allocation and payment of pensions, benefits and other payments.

Other institutions that perform specific functions related to social insurance are also participants in the Lithuanian social insurance system: the State Tax Inspectorate, the State Health Insurance Fund, the Social Insurance Reserve Fund, and the Employment Service [14].

Policyholders are legal entities, other organizations, or their subdivisions (branches, representative offices), as well as natural persons who are obliged to pay state social insurance contributions following the procedure established by law. Insured persons are natural persons who, in accordance with the procedure established by this law, pay state social insurance contributions themselves or these contributions are paid by policyholders for them [14].

\section{MANAGEMENT OF RECOVERY OF SOCIAL INSURANCE CONTRIBUTIONS IN THE TERRITORIAL DIVISION OF MAŽEIKIAI}

The Board of the State Social Insurance Fund manages the activities of ten territorial divisions of Lithuania. For a more detailed description of the management of social insurance contributions, we will examine the case of Mažeikiai Territorial Division.

The level of contribution collection in Mažeikiai division has been higher than the Lithuanian average in recent years (see Table 2): 
Table 2. Level of contribution collection in Lithuania and Mažeikiai division, in percentage

\begin{tabular}{|c|c|c|c|c|c|}
\hline & $\mathbf{2 0 1 4}$ & $\mathbf{2 0 1 5}$ & $\mathbf{2 0 1 6}$ & $\mathbf{2 0 1 7}$ & $\mathbf{2 0 1 8}$ \\
\hline Lithuania & 92.28 & 91.87 & 90.35 & 90.84 & 89.12 \\
\hline $\begin{array}{c}\text { Mažeikiai } \\
\text { division }\end{array}$ & 92.74 & 91.92 & 92.52 & 93.08 & 93.79 \\
\hline
\end{tabular}

Source: Compiled by the authors according to [15]

The structure of the collection of contributions of Mažeikiai division in 2018 shows that the largest number of contributions, even 91.52 percent, was recovered by payment orders from credit institutions, i.e. debiting funds from policyholders' bank accounts. Income received from policyholders within due time amounted to 6.99 percent. Revenue from payment orders from employers and bailiffs and bankruptcy proceedings makes a very small share, 0.24 percent, 0.36 percent, and 0.89 percent, respectively.

The Money Restriction Information System (PLAIS) introduced in 2015 helps to combat not only the non-repayment of debts of natural persons, but also the delay of legal persons in transferring taxes or contributions to the state institutions.

The amounts of recovery orders submitted to credit institutions for recovery (blue column, in EUR'000) and the amounts received (brown column, in EUR'000) and the recovery percentage (line) of Mažeikiai division for the year 2014-2017 are shown in Figure 2:

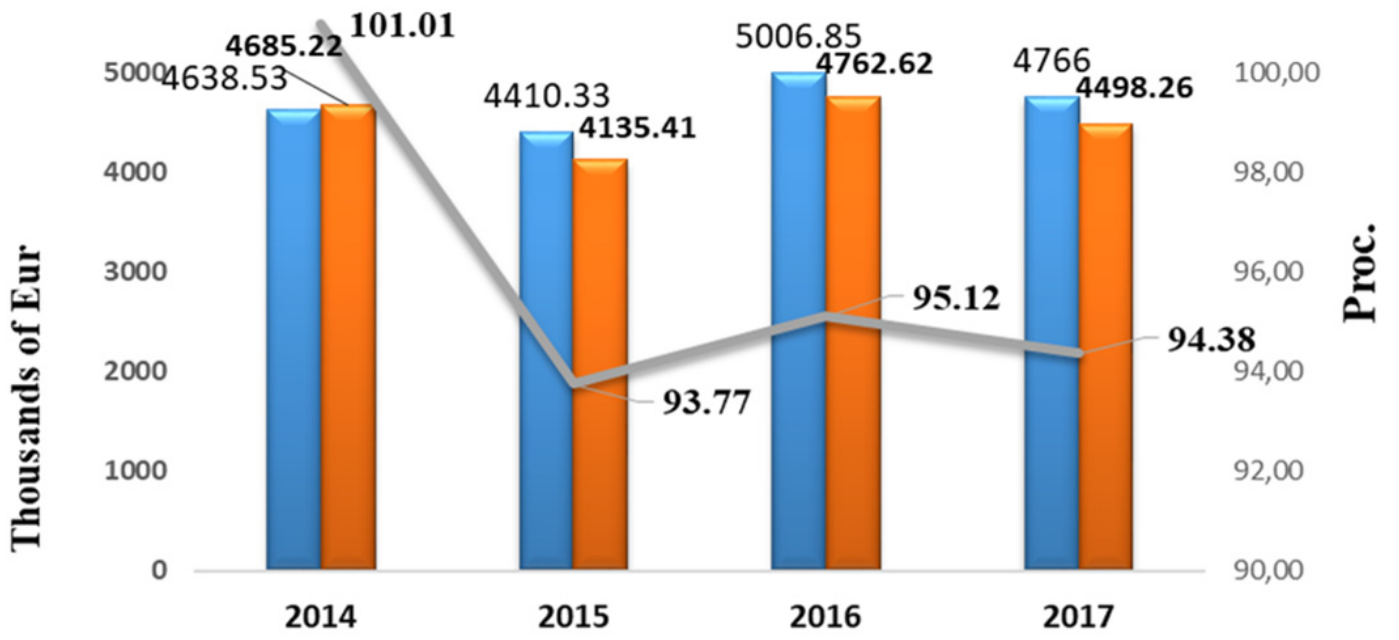

Fig. 2. Amounts transferred and recovered to credit institutions (in EUR'000) and recovery percentage, Source: Compiled by the authors according to [15]

The situation is much worse, although here the amounts are much lower, when recovering 
debts from policyholders who receive a salary, pension, scholarship or other benefit. Table 3 shows the amounts transferred for recovery and income received in EUR'000 in 2014-2018:

Table 3. Amounts transferred to recover from salaries, pensions, scholarships and other benefits and amounts received

\begin{tabular}{|c|c|c|c|}
\hline Year & $\begin{array}{c}\text { Transferred to recover (in } \\
\text { EUR'000) }\end{array}$ & $\begin{array}{c}\text { Received from } \\
\text { policyholder (in } \\
\text { EUR'000) }\end{array}$ & Recovery percentage \\
\hline $\mathbf{2 0 1 4}$ & 70.3 & 12.39 & 17.62 \\
\hline $\mathbf{2 0 1 5}$ & 69.96 & 15.48 & 22.13 \\
\hline $\mathbf{2 0 1 6}$ & 69.85 & 13.57 & 19.43 \\
\hline $\mathbf{2 0 1 7}$ & 108.15 & 12.63 & 11.68 \\
\hline $\mathbf{2 0 1 8}$ & 5132.95 & 12.73 & 0.25 \\
\hline
\end{tabular}

Source: Compiled by the authors according to [15]

A debt recovery level of less than 20 percent is, of course, unsatisfactory. This situation in Mažeikiai division was especially aggravated by the decision to transfer the functions of payment and recovery of child maintenance benefits to Mažeikiai division from 2018. According to this decision, the number of such policyholders to whom amounts from their salaries, pensions, scholarships and other benefits were transferred for recovery increased from 53 (in 2017) to 1368 (in 2018) in Mažeikiai division. As it is often difficult to recover child maintenance benefits, in 2018, the percentage of recovery of such debts in Mažeikiai division was only 0.25. In addition, by the Government Resolution, from 2018, the percentage of deductions from income exceeding the minimum monthly salary has been reduced (deductions from income not exceeding the minimum monthly salary (in 2021, it will be $€ 642$ ) are not possible).

A similarly bad situation is when territorial divisions outsource the recovery of contributions, benefits, late payment, interest and fines to bailiffs. Bailiffs are usually entrusted with recovery from indebted policyholders who have assets. However, indebted policyholders usually do not have registered assets. Often, debtors are socially disadvantaged and recovery from social benefits is not possible. Recovery from unemployment benefits can only take place with the consent of the debtor. When debtors cannot be found at the address of residence or the debtor's place of residence is unknown and if the debt is more than $€ 350$, the territorial division may apply to the bailiff to have the debtor searched through the police system. 
Territorial divisions have the right to initiate bankruptcy proceedings against indebted policyholders. Some companies pay the full debt immediately after receiving court proceedings for bankruptcy. However, in most cases, when a bankruptcy case is initiated, the debtor's assets no longer exist or the assets are insignificant. In addition, according to the Government Resolution, from 2020, the first step is to try to recover the debt through the submitted payment instructions to credit institutions, and only if such recovery fails it is possible to initiate bankruptcy proceedings through the court.

Territorial divisions of the Board of the Lithuanian Social Insurance Fund have the right to apply for debt recovery to the relevant institutions of the European Union, European Economic Area countries or the Swiss Confederation, as well as these institutions apply to Lithuanian territorial divisions. The Administrative Commission for the Coordination of Social Security Systems of the European Union has adopted special forms for this mutual cooperation: R017 - for debt recovery; R012 - for information on the address, income, assets of the policyholders in debt; H001 - for information on the insurance of indebted policyholders.

Debt collection abroad (Form R017) performed by Mažeikiai division in 2016-2018 was not very effective, about one-third of the requests submitted to foreign institutions were fulfilled (see Table 4):

Table 4. Amounts transferred and recovered from salaries, pensions, scholarships and other benefits and amounts received

\begin{tabular}{|c|c|c|c|}
\hline Year & $\begin{array}{c}\text { Number of requests } \\
\text { submitted }\end{array}$ & $\begin{array}{c}\text { Number of completed } \\
\text { requests }\end{array}$ & $\begin{array}{c}\text { Funds recovered, in } \\
\text { euros }\end{array}$ \\
\hline $\mathbf{2 0 1 6}$ & 45 & 16 & 11326 \\
\hline $\mathbf{2 0 1 7}$ & 46 & 11 & 8599 \\
\hline $\mathbf{2 0 1 8}$ & 24 & 8 & 5586 \\
\hline
\end{tabular}

Source: Compiled by the authors according to [15]

Experience shows that debt recovery abroad takes between 3 months and 1 year, as at present the exchange of information between the competent social security institutions of the Member States still takes place mainly in the form of paper documents. The regulations on the coordination of social security systems in the European Union provide for the transition to the electronic exchange of information. This will be done through electronic social security information exchange system, which is currently being finalized. The scheme will be open to all Member States of the European Union, the countries of the European Economic Area and 
Switzerland. The electronic system will enable all connected institutions to exchange information much faster and more securely.

\section{CONCLUSIONS}

The analysis of the situation of the management of the collection of state social insurance contributions in Lithuania enabled us to envisage directions for the improvement of the management of this collection. The main direction is to increase the efficiency of the collection of state social insurance contributions. This direction is closely related to the state's general policy of improving economic conditions and its implementation. The tax system must be designed in such a way as to promote the development of the country's economy and reduce the opportunities for tax avoidance, create conditions for avoiding insolvency, and make fair and timely tax payment the most promising way to remain competitive in the labour market. In addition, as the economic and political situation of the state changes, the tax system must also change rapidly. In recent years, the level of collection of social insurance contributions in Lithuania has fluctuated around 90 percent, but the activities of Mažeikiai Territorial Division show that it is possible to reach the level of collection of 94 percent of contributions.

An important direction for the improvement of the management of the collection of social insurance contributions in Lithuania could be the transition to the universal electronic exchange of information of the social security system with other business and public sector institutions. The use of information technology and specialized software would not only increase efficiency, but also enable more efficient finding of debtors and recovery of unpaid taxes.

In order to improve the level of collection of social insurance contributions, closer cooperation between the Board of the Lithuanian Social Insurance Fund and its 10 territorial divisions is important not only with debt collection institutions, but above all, with business and other organizations interested in improving labour market conditions and public employment culture and honesty. The education system should also play an important role here in developing the basics of fair behaviour, respect for the state and its economy.

\section{REFERENCES}

[1] Lietuvos Respublikos Mokesčiu administravimo įstatymas. Priėmė Lietuvos Respublikos Seimas, 2004-04-13, Nr. IX-2112. Vilnius. 
[2] Balkevičius, A. (2017). Biudžeto rizikos valdymas. Vİ Registrų centras, Vilnius.

[3] Konvisarova, E., Samsonova, I., Vorozhbit, O. (2015). The Nature and Problems of Tax Administration in the Russian Federation. Mediterranean Journal of Social Sciences, vol. 5, no. 3, p. $78-83$.

[4] Guogis, A., Bogdanova, N. (2012). Sovietinio socialinès apsaugos modelio funkcijos bei raida ir Lietuva. Politologija, vol. 66, no. 2, p. 32-77.

[5] Buškevičiūtè, E. (2006). Viešieji finansai. Technologija, Kaunas.

[6] Lietuvos pažangos strategija „Lietuva 2030“. Patvirtinta Lietuvos Respublikos Seimo 2012 m. gegužès 15 d. nutarimu Nr. XI-2015. Vilnius.

[7] Priverstinio poveikio priemoniu taikymo taisykles. Patvirtintos Valstybinio socialinio draudimo fondo valdybos prie Socialinès apsaugos ir darbo ministerijos direktoriaus $2009 \mathrm{~m}$. sausio 21 d. įsakymu Nr. V-32. Vilnius.

[8] Marčauskienè, A. (2016). Ar Lietuvos Respublikos bankroto įstatyme nustatyti kriterijai ịmonès nemokumo ịvertinimui užtikrina, kad nebūtų pradèta bankroto procedūra ịmonèms turinčioms laikinų finansinių sunkumų. Teisès apžvalga, vol. 13, no. 1, p. 44-85.

[9] Jurkaitienè, S., Kiyak, D., Bružaitè, E. (2017). Verslo aplinkos veiksniu ịtaka įmoniu mokumui. Klaipėdos universitetas, Klaipėda.

[10] Butkus, M., Žakarè, S., Cibulskienè, D. (2014). Bankroto diagnostikos modelis ir jo pritaikymas bankroto tikimybei Lietuvos imonèse prognozuoti. Applied Economics: Systematic Research, vol. 8, no. 1, p. 111-132.

[11] Strunkienè, I. (2018). Nemokumo reglamentai: ar užkirstas kelias nesąžiningam fizinio asmens palankesnio teisinio reglamentavimo ieškojimui? Jurisprudencija, vol. 25, no. 2, p. 527-546.

[12] Lietuvos statistika. Oficialiosios statistikos portalas, from https://osp.stat.gov.lt/, accessed on 2020-12-28.

[13] Lietuvos Respublikos Seimas. Patvirtintas $2021 \mathrm{~m}$. „Sodros“ biudžetas, from https://www.lrs.lt/sip/portal.show?p_r=35435\&p_k=1\&p_t=273975\&p_kade_id=9, accessed on 2020-12-28.

[14] Lietuvos Respublikos valstybinio socialinio draudimo isstatymas. Prièmè Lietuvos Respublikos Aukščiausioji Taryba - Atkuriamasis Seimas, 1991-05-21, Nr. I-1336. Vilnius. [15] Teritoriniai skyriai. Mažeikių skyrius, from https://www.sodra.lt/lt/teritoriniaiskyriai/poskyris/?id=176, accessed on 2020-12-29. 